\title{
PENGARUH PEMBERIAN SARI KURMA TERHADAP KENAIKAN HEMOGLOBN PADA REMAJA
}

\author{
Astik Umiyah,S.ST., M.Kes. ${ }^{1}$, Selvia Nurul Qomari ${ }^{2}$, Dina Al Habsyi ${ }^{3}$ \\ S1 Kebidanan Fakultas Ilmu Kesehatan Universitas Ibrahimy ${ }^{13}$ \\ STIKES Ngudia Husada Madura ${ }^{2}$ \\ Email : ${ }^{1}$ astik.umiyah86@gmail.com
}

\begin{abstract}
Women have a high risk of suffering from anemia, especially in teenage girl. Anemia can affect teenage girl growth and development, the body during infancy is easily infected, decreased enthusiasm for learning. The purpose of this research is to know the effect of giving palm juice to the increase in hemoglobin levels in teenage girl who have anemia in dorm Ma'had Aly Pondok Pesantren Salafiyah Syafi 'iyah Sukorejo Situbondo 2018. This study used a pre experiment design with a sample of 35 respondents who met the iclusion criteria with a total sampling technique. The treatment was given date palm juice to 35 respondents. Analysis was done using paired sample T test. Statistical test result show significant value $(p<0,05)$ the meaning is that there is an effecf of giving palm juice to the increase in respondents who have anemia. Giving date palm juice can increase hemoglobin levels because the nutrient content contained in date palm juice is very effective in raising hemoglobin levels in the blood. Expect that the provision of date palm juice still needs to be continued, and the need for counseling to teenage girl in order to increase knowledge about nutrition and health and food intake.
\end{abstract}

Keywords:teenage girl, anemia, palm juice

\begin{abstract}
ABSTRAK
Wanita memunyai risiko tinggi menderita anemia, terutama pada masa remaja. Anemia dapat berdampak pada tumbuh kembang remaja, tubuh pada masa pertumbuhan mudah terinfeksi, semangat belajar menurun. Tujuan penelitian mengetahui adanya pengaruh pemberian sari kurma terhadap kenaikan kadar hemoglobin pada remaja puteri yang mengalami anemia di Asrama Ma'had Aly Pondok Pesantren Salafiyah Syafi'iyah Sukorejo Situbondo Tahun 2018. Penelitian ini menggunakan pre ekperiment design dengan sampel 35 responden yang memenuhi criteria inklusi dengan teknik total sampling. Perlakuan diberikan sari kurma kepada 35 responden. Analisa data menggunakan uji T paired sample. Hasil uji statistik menunjukkan nilai signifikan $(\mathrm{p}<0,05)$ artinya adalah ada pengaruh pemberian sari kurma terhadap kenaikan kadar hemoglobin pada responden yang mengalami anemia. Pemberian sari kurma mampu meningkatkan kadar hemoglobin karena kandungan nutrisi yang terdapat dalam sari kurma sangat efektif dalam menaikkan kadar hemoglobin dalam darah. Harapkan pemberian sari kurma masih perlu dilanjutkan, serta perlunya penyuluhan pada remaja agar dapat meningkatkan pengetahuan tentang gizi dan kesehatan serta asupan makan.
\end{abstract}

Kata kunci : : Remaja Puteri, Anemia, Sari Kurma

\section{PENDAHULUAN}

Anemia adalah suatu keadaan kekurangan kadar hemoglobin $(\mathrm{Hb})$ dalam darah, secara fisiologis anemia terjadi apabila terdapat kekurangan jumlah hemoglobin untuk mengangkut oksigen ke jaringan ${ }^{(1)}$. Hemoglobin merupakan protein berupa pigmen merah pembawa oksigen yang kaya zat besi dan memiliki daya gabung terhadap oksigen untuk membentuk hemoglobin dalam sel darah merah ${ }^{(2)}$.
Remaja putri merupakan kelompok risiko tinggi mengalami anemia atau kelompok yang lebih rentan mengalami anemi dibandingkan dengan remaja putra, dimana kebutuhan absorpsi zat besi memuncak pada umur 14-15 tahun pada remaja putri, sedangkan pada remaja putra satu atau dua tahun berikutnya. Sebab itulah kebutuhan zat besi pada remaja putri tiga kali lebih besar dari pada putera, karena setiap bulan mengalami menstruasi yang secara otomatis mengeluarkan darah ${ }^{(3)}$. Remaja putri dan putra menderita defisiensi $\mathrm{Fe}$, dan anemia $\mathrm{Fe}$ karena 
meningkatnya kebutuhan Fe selama proses pertumbuhan ${ }^{(4)}$. Kejadian anemia yang masih banyak pada remaja dikarenakan kurangnya asupan zat besi, meningkatnya kebutuhan zat besi, aktifitas fisik, menstruasi yang terlalu banyak, perilaku hidup bersih dan sehat sehingga berakibat pada remaja putri yang sering mengantuk pada pagi hari, sering pusing, lemas, mengakibatkan muka pucat. Menurut (WHO) anemia muncul karena kekurangan zat besi.

Di Indonesia, anemia merupakan salah satu masalah kesehatan utama. Organisasi Kesehatan Dunia (WHO) menyatakan bahwa berkurangnya anemia secara global, akan memberikan kontribusi yang besar untuk pencapaian Millennium Development Goals ${ }^{(5)}$. Prevalensi anemia di Indonesia yaitu 21,7\% dengan penderita anemia berumur 514 tahun sebesar $26,4 \%$ dan $18,4 \%$ penderita berumur 15-24 tahun (Kemenkes RI, 2014). Menurut penelitian $^{(6)}$ di Propinsi Jawa Timur berdasarkan dari hasil survey anemia pada Wanita Usia Subur (WUS) berusia antara 15 tahun atau sudah pernah haid (menstruasi) sampai dengan usia 25 tahun di Pondok Pesantren Tahun 2006 di 5 (lima) kabupaten (Lamongan, Kediri, Situbondo, Jember, Sampang) diketahui rata-rata prevalensi anemia sebesar 38,1 \%, sedangkan untuk Kabupaten Situbondo sendiri ditemukan prevalensi $28,0 \%$. Prevalensi tersebut menjadi Public Health Problem bagi remaja putri karena sudah diatas $10 \%$.

Buah kurma merupakan makanan yang mengandung energi tinggi dengan komposisi ideal, didalamnya memiliki kandungan karbohidrat, triptofan, omega3, vitamin $\mathrm{C}$, vitamin $\mathrm{B} 6, \mathrm{Ca} 2+, \mathrm{Zn}$, dan $\mathrm{Mg}$. Buah kurma mengandung serat yang sangat tinggi, selain itu juga mengandung kalium, mangan, fosfor, besi, belerang, kalsium juga magnesium yang sangat baik untuk dikonsumsi ${ }^{(7)}$. Sari kurma merupakan kurma yang dihaluskan dan diambil sarinya, berbentuk cair, kental, berwarna hitam dan terasa manis serta mengandung zat gizi yang lengkap seperti buah kurma ${ }^{(8)}$. Dengan kandungan yang lengkap, diharapkan sari kurma dapat meningkatkan kadar hemoglobin pada remaja.

Sari kurma bermanfaat bagi kesehatan antara lain dapat membantu memperbaiki sistem pencernaan karena mengandung serat larut dan asam amino bagi tubuh, sebagai penguat energi yang besar karena mengandung gula alami seperti glukosa, sukrosa dan fruktosa, membantu mengatur sistem saraf yang sehat, memiliki kandungan zat besi yang tinggi dan sangat berguna dalam mengobati anemia. Prof dr Zaglul an-Najjar dan dr. Abdul Baim Kahli mengemukakan bahwa kurma mengandung dampak yang sangat aktif sekali dalam tubuh. Kurma memiliki pengaruh yang sangat besar terhadap hemoglobin (zat pewarna dalam darah).

Berdasarkan hasil studi pendahuluan yang dilakukan dengan cara melakukan pemeriksaan fisik (pucat yang dilihat pada daerah kuku, jari, konjungtiva, mudah mengantuk, sering pusing, mudah lelah) dan tes $\mathrm{Hb}$ (dengan hasil di bawah $12 \mathrm{gr} / \mathrm{dl}$ ) dari jumlah remaja yang ada diketahui sebanyak 35 remaja di Asrama Ma'had Aly Sukorejo Situbondo per bulan juli Tahun 2017, semuanya (100) remaja yang mengalami anemia. Berdasarkan pernyataan tersebut peneliti tertarik untuk meneliti dengan topik Pengaruh Kenaikan Hemoglobin Pada Remaja Dengan Intervensi Sari Kurma di Asrama Ma'had Aly Putri tahun 2018.

\section{METODE}

Penelitian ini menggunakan on group preeksperimen posteksperimen. Dalam penelitian ini menggunakan metode total sampling sebanyak 35 remaja yang sudah menstruasi dan mengalami anemia diberikan sari kurma. Lokasi penelitian dilakukan di asrama Ma'had Aly putri pada bulan Juni 2018. Instrument yang digunakan adalah pemeriksaan fisik dan lab sederhana. Uji statistik yang digunakan uji paired sample t-test.

\section{HASIL}

\section{Karakteristik Usia Responden Penelitian}

Tabel 1. Distribusi Frekuensi Karakteristik Remaja Puteri yang Mengalami Anemia di Asrama Ma'had Aly Pondok Pesantren Salafiyah Syafi'iyah Sukorejo Situbondo Tahun 2018.

\begin{tabular}{|llcc|}
\hline No & \multicolumn{1}{c}{$\begin{array}{c}\text { karakteristik } \\
\text { respomden }\end{array}$} & f & $(\%)$ \\
\hline 1. & Umur & 15 & 42,86 \\
& $15-16$ tahun & 20 & 57,14 \\
\hline & $17-18$ tahun & 35 & 100 \\
\hline & Jumah & & \\
\hline 2. & Pendidikan & &
\end{tabular}




\begin{tabular}{|lcc|} 
SMA-SMK & 21 & 60 \\
PT & 14 & 40 \\
\hline Jumah & 35 & 100
\end{tabular}

Bersadarkan hasil penelitian pada data table 1 dari 35 responden terlihat sebagian besar usia antara 17-18 tahun, rata-rata usia responden tidak beda jauh berkisar anatar 15-18 tahun yaitu selisihnya berkisar 1-2 tahan dimana kondisi ini menurut Monks (2009) merupakan kategori remaja pertengahan dan akan memasuki remaja akhir. Ditinjau dari sisi pendidikan didominasi sebagian besarnya masih dalam proses pendidikan SMA/SMK.

\section{Dosis Pemberian Sari Kurma}

Tabel 2 Distribusi Frekuensi Dosis Pemberian Sari Kurma pada Remaja Puteri yang Mengalami Anemia di Asrama Ma'had Aly Pondok Pesantren Salafiyah Syafi'iyah Sukorejo Situbondo Tahun 2018.

\begin{tabular}{|c|c|c|c|c|c|}
\hline $\begin{array}{l}\mathrm{n} \\
\mathrm{o}\end{array}$ & $\begin{array}{l}\text { pemb } \\
\text { erian }\end{array}$ & Dosis & waktu & $\mathrm{f}$ & $(\%)$ \\
\hline 1 & $\begin{array}{l}\text { Sari } \\
\text { kurma }\end{array}$ & $\begin{array}{l}1 \\
\text { sendok } \\
\text { makan }\end{array}$ & $\begin{array}{l}2 \mathrm{x} \\
\text { dalam } 1 \\
\text { hari }\end{array}$ & 35 & 100 \\
\hline \multicolumn{4}{|c|}{ Total } & 35 & 100 \\
\hline
\end{tabular}

Berdasarkan tabel 2 bahwa setiap responden diberikan sari kurma dengan dosis 1 sendok makan $2 \mathrm{x}$ sehari diberikan pada 35 responden dengan kategori anemia sedang karena banyaknya remaja yang mengalami anemia.

3. Kadar Hemoglobin Sebelum Diberikan Sari Kurma

Tabel 3 Distribusi Frekuensi Kadar Hemoglobin Sebelum Diberikan Sari Kurma pada Remaja Puteri yang Mengalami Anemia di Asrama Ma'had Aly Pondok Pesantren Salafiyah Syafi'iyah Sukorejo Situbondo Tahun 2018

\begin{tabular}{|c|c|c|c|}
\hline No. & $\begin{array}{l}\text { Hemoglobin sebelum } \\
\text { diberikan sari kurma } \\
\text { (gr/dl) }\end{array}$ & f & $(\%)$ \\
\hline 1 & $8.0-9.0$ & 22 & 62.8 \\
\hline 2 & $9.1-10.0$ & 12 & 34.3 \\
\hline 3 & $10.1-11.0$ & 1 & 2.9 \\
\hline 4 & $11.1-12.0$ & 0 & 0 \\
\hline 5 & $12.1-13.0$ & 0 & 0 \\
\hline
\end{tabular}

Total

$35 \quad 100$

Berdasarkan tabel 3 dari 35 responden dilakukan pemeriksaan kadar $\mathrm{Hb}$ diperoleh Sebagian besar kadar $\mathrm{Hb}$ antara 8.0-9.0 gr/dl. Hasil tersebut dilakukan sebelum diberikan perlakukan dan responden hampie seluruhnya dalam kategori anemia sedang.

4. Kadar Hemoglobin Sesudah Diberikan Sari Kurma

Tabel 4 Distribusi Frekuensi Kadar Hemoglobin Sesudah Diberikan Sari Kurma pada Remaja Puteri yang Mengalami Anemia di Asrama Ma'had Aly Pondok Pesantren Salafiyah Syafi'iyah Sukorejo Situbondo Tahun 2018.

\begin{tabular}{|c|c|c|c|}
\hline no & $\begin{array}{l}\text { Hemoglobin } \\
\begin{array}{l}\text { diberikan sesudah } \\
\text { (gr/dl) }\end{array}\end{array}$ & $\mathrm{f}$ & $(\%)$ \\
\hline 1 & $8.0-9.0$ & 9 & 25.7 \\
\hline 2 & $9.1-10.0$ & 8 & 22.9 \\
\hline 3 & $10.1-11.0$ & 8 & 22.9 \\
\hline 4 & $11.1-12.0$ & 10 & 28.5 \\
\hline 5 & $12.1-13.0$ & 0 & 0 \\
\hline \multicolumn{2}{|r|}{ Total } & 35 & 100 \\
\hline
\end{tabular}

Berdasarkan tabel 4 dari 35 responden dilakukan pemeriksaan kadar $\mathrm{Hb}$ diperoleh hampir setengahnya kadar $\mathrm{Hb}$ antara 11.1-12.0 gr/dl. Hasil tersebut dilakukan setelah diberikan perlakukan dan rata-rata kondisi tersebut mengalami peningkatan kadar Hb. Tergambarkan dari tabel 6 bahwa seluruhnya responden mengalami peningkatan kadar $\mathrm{Hb}$ dari kadar sebelumnya, meskipun belum dinyatakan alam kondisi $\mathrm{Hb}$ normal.

Tabel 5 Distribusi Frekuensi Kenaikan Kadar Hemoglobin pada Remaja Puteri yang Mengalami Anemia di Asrama Ma'had Aly Pondok Pesantren Salafiyah Syafi'iyah Sukorejo Situbondo Tahun 2018.

\begin{tabular}{|c|l|c|c|}
\hline no & \multicolumn{1}{|c|}{ diberi sari kurma } & f & $(\%)$ \\
\hline 1. & $\begin{array}{l}\text { Kadar hemoglobin naik } \\
\text { Kadar hemoglobin tidak } \\
\text { naik }\end{array}$ & 35 & - \\
\hline \multicolumn{2}{|c|}{ Total } & - \\
\hline \multicolumn{2}{|c|}{} \\
\hline
\end{tabular}

5. Pengaruh Pemberian Sari Kurma Sebelum dan Sesudah 

Vol. 16 No. 3 September - Desember 2021

Tabel 6 Distribusi Frekuensi Pemberian Sari Kurma Sebelum an Sesudah di Asrama Ma'had Aly Pondok Pesantren Salafiyah Syafi'iyah Sukorejo Situbondo Tahun 2018.

\begin{tabular}{|l|l|c|c|c|c|}
\hline \multirow{2}{*}{ No } & \multirow{2}{*}{ Kadar $\mathrm{Hb}$} & \multicolumn{4}{|c|}{ Perlakuan } \\
\cline { 3 - 6 } & & Pre & $\mathrm{f}$ & Post & $\mathrm{f}$ \\
\hline 1 & $8.0-9.0$ & 22 & 62.8 & 9 & 25.7 \\
\hline 2 & $9.1-10.0$ & 12 & 34.3 & 8 & 22.9 \\
\hline 3 & $10.1-11.0$ & 1 & 2.9 & 8 & 22.9 \\
\hline 4 & $11.1-12.0$ & 0 & 0 & 10 & 28.5 \\
\hline 5 & $12.1-13.0$ & 0 & 0 & 0 & 0 \\
\hline \multicolumn{7}{|c|}{ Total } & 35 & 100 & 35 & 100 \\
\hline
\end{tabular}

Tabel 7 Distribusi Frekuensi Pemberian Sari Kurma di Asrama Ma'had Aly Pondok Pesantren Salafiyah Syafi'iyah Sukorejo Situbondo Tahun 2018.

\begin{tabular}{|c|c|c|c|c|c|c|c|}
\hline \multirow{2}{*}{$\begin{array}{c}\text { Perlak } \\
\text { uan }\end{array}$} & \multicolumn{2}{|c|}{ Hb naik } & \multicolumn{2}{|c|}{$\begin{array}{c}\mathrm{Hb} \\
\text { tidak } \\
\text { naik }\end{array}$} & \multicolumn{2}{|c|}{ total } & \multicolumn{2}{|c|}{$\begin{array}{c}\text { p.valub } \\
\text { e }\end{array}$} \\
\cline { 2 - 9 } & $\mathrm{F}$ & $\%$ & $\mathrm{f}$ & $\%$ & $\mathrm{f}$ & $\%$ & \multicolumn{2}{|c|}{} \\
\hline $\begin{array}{l}\text { Diberi } \\
\text { sari } \\
\text { kurma }\end{array}$ & 35 & 100 & - & - & 35 & 100 & 0,000 \\
\hline
\end{tabular}

Berdasarkan tabel 7 diperoleh kenaikan kadar hemoglobin pada remaja puteri yang mengalami anemia yang diberi Sari Kurma seluruhnya kadar hemoglobin naik yaitu sebesar 35 responden $(100 \%)$. Sementara dari hasil penghitungan data penelitian dengan menggunakan uji " $T$ paired sample" dengan penghitungan menggunakan software SPSS 16 pada tingkat kemaksimalan $(\alpha=0,05)$ diperoleh informasi nilai Asymp. Sig. $=000$, karena nilai tersebut $<$ taraf signifikan $(\alpha=0,05)$, dengan demikian Ho ditolak dan Ha diterima yang berarti ada pengaruh pemberian sari kurma terhadap Kenaikan kadar hemoglobin pada remaja puteri.

\section{PEMBAHASAN}

Sebagian besar responden berusia 17-18 tahun yaitu sebanyak 20 orang $(57,14 \%)$. Penderita anemia paling banyak berada pada saat remaja. Hal ini dikarenakan pada usia remaja mengalami menstruasi setiap bulannya yang akan berpengaruh kehilangan zat besi pada saat menstruasi, sedangkan remaja pada usia ini tidak memperhatikan asupan zat gizi yang dikonsumsikan untuk mengembalikan zat besi yang hilang karena menstruasi.

Sesuai penelitian mengenai kejadian anemia pada siswa SMK N dan mendapatkan hasil terdapat hubungan yang bermakna antara asupan makanan (zat gizi) dengan kejadian anemia pada siswa SMKN I Buduran Sidoarjo ${ }^{(10)}$. Penelitian lain yang menyatakan bahwa hubungan antara pola menstruasi terhadap anemia pada remaja India, dengan hasil prevalensi anemia adalah 90,83\%. Anemia secara bermakna dikaitkan dengan panjang siklus menstruasi serta adanya dismenorea dan sindrom pramenstruasi tapi tidak dengan usia menarche dan durasi aliran darah. Secara signifikan lebih banyak jumlah remaja dengan anemia memiliki siklus menstruasi tidak teratur, dismenorea dan sindrom pramenstruasi. Faktor risiko anemia lain yang pernah diteliti yaitu status gizi dengan berbagai indikator pengukuran (1). Hasil penelitian yang berbeda ditunjukkan valubahwa asupan zat gizi dan pola menstruasi dengan

kejadian anemia pada remaja putri di Semarang dengan hasil tidak terdapat hubungan antara pola menstruasi dengan kejadian anemia, dikuatkan dengan penelitian yang menyatakan penyebab anemia bukan hanya asupan gizi dan kehilangan darah yang terus menerus melainkan absorbsi zat besi yang rendah, infeksi cacing, asupan protein dan sosial ekonomi yang rendah ${ }^{(12,13)}$. Data khusus yang didapatkan dari pemberian sari kurma didapatkan sebanyak $(100 \%)$ responden kadar hemoglobinnya naik dalam waktu 2 hari.

Sari kurma merupakan obat yang sangat diminati oleh responden, selain itu pengetahuan tentang sari kurma sudah lumrah diketahui oleh semua orang ,bahwa sari kurma sangat baik untuk kesehatan, tetapi mereka belum mengetahui manfaat sari kurma untuk kesehatan terutama untuk kenaikan hemoglobin. Demikian juga sari kurma terbukti sangat bermanfaat untuk menyembuhkan berbagai penyakit dan dapat dikonsumsi kapan saja, tanpa efek samping yang dapat merugikan.

Dalam penelitian ini responden diberikan dosis sebanyak 1 sendok makan $2 \mathrm{x}$ sehari dengan anemia sedang karena banyaknya remaja yang mengalami anemia dalam kategori anemia sedang. Buah kurma merupakan makanan yang mengandung energi tinggi dengan komposisi ideal, didalamnya memiliki kandungan karbohidrat, triptofan, omega3, vitamin $\mathrm{C}$, vitamin $\mathrm{B} 6, \mathrm{Ca} 2+, \mathrm{Zn}$, dan Mg. Buah kurma 
mengandung serat yang sangat tinggi, selain itu juga mengandung kalium, mangan, fosfor, besi, belerang, kalsium juga magnesium yang sangat baik untuk dikonsumsi ${ }^{(7)}$

\section{KESIMPULAN}

Dengan memperhatikan hasil pennelitian dan pembahasan dapat disimpulkan bahwa konsumsi sari kurma diberikan pada 35 remaja putri dengan dosis sebanyak 1 sendok makan setiap hari selama 2 hari terdapat pengaruh terhadap kenaikan kadar hemoglobin pada remaja putri yang mengalami anemia yang dibuktikan dengan hasil pada tingkat kemaksimalan $(\alpha=$ $0,05)$ diperoleh hasil Sign. Sebesar 0,000 sehingga $\mathrm{H}_{0}$ diterima dan Ha ditolak artinya tidak signifikan.

\section{DAFTAR PUSTAKA}

1. Astawan. Khasiat warna warni makanan: Jakarta; PT Gramedi Pustaka; 2008.

2. Syaifuddin. Anatomi fisiologi kurikulum berbasis kompetensi: Jakarta; EGC; 2012

3. Proverawati. Buku Kesehatan Keperawatan dan Kebidanan. Jakarta ; Nuha Medika; 2011.

4. Kirana, D. P.. Hubungan Asupan Zat Gizi dan Pola Menstruasi dengan Kejadian Anemia pada Remaja Putri: Universitas Diponegoro; Semarang; 2011.

5. World Health Organization, "Haemoglobin concentrations for the diagnosis of anemia and Assessment of severity," Vitamin and Mineral Nutrition Information System, 2011. [Online]. Available:https://www.who.int/vmnis/indicat or s/haemoglobin/en/.

6. Chuluq Ar, A. Chusnul,dkk.. Hubungan Intake Zat Besi (Fe), Inhibitor, dan Enhancer Dengan Kadar Hemoglobin Remaja Putri (Studi Kasus Di SMAN 1 Panarukan Kecamatan Panarukan, Kabupaten Situbondo); Fakultas Kedokteran Universitas Brawijaya. Jurnal www.fkub.ac.id. 2012.

7. S. Baliga, "A Review Of The Chemistry And Pharmacology of Date Fruits (Phoenix Dactylifera. L)," Food Research International, vol. 44, no. 47, pp. 1812-1822, 2011.

8. T. H. Mallhi, M. Ali, M. I. Qadir and B. Ahmad, "Ajwa Date (Phoenix dactylifera): An Emerging Plant in Pharmacological Research," Pakistan journal of pharmaceutical sciences, vol. 27, no. 3, pp. 607-616, 2014.

9. Monks, Tahap Perkembangan Masa Remaja. Medical Journal New Jersey Muagman, 1980.
Defenisi Remaja; Jakarta : Penerbit Grafindo Jakarta; 2009.

10.Kurnia, F.. Hubungan asupan makanan dengan kejadian anemia dan nilai praktik pada siswa kelas XI Boga SMKN 1 Buduran Sidoarjo. EJornal Boga, 3(februari) 2014. p.46-53; Retrievedfromhttp://www.scribd.com/docume nt_downloads/200865992? extension=pdf \&fro $\mathrm{m}=\mathrm{embed} \&$ source $=\mathrm{embed}$

11.Rupali, P. A., Sanjay, K. S., \& Patle,. Anemia: Does it Have Effect on Menstruation? Scholars Journal of Applied Medical SciencesOnline) Sch. J. App. Med. Sci, 3(1G).2015. 514-517. Retrieved from www.saspublisher.com

12.Kirana, D. P. Hubungan Asupan Zat Gizi dan Pola Menstruasi dengan Kejadian Anemia pada Remaja Putri; Universitas Diponegoro; Semarang; 2011

13.Fajrin A. Faktor risiko sosial ekonomi, asupan protein, asupan zat besi terhadap kejadian anemia pada anak sekolah; Jurnal Gizi Indonesia Volume 35 (1) 2012: 22-29. 